\title{
CNRS under fire from staff
}

Paris. About 20 French researchers have formed an association, SOS Recherche, to fight against what they describe as abuse of power, favouritism, and unfair discrimination by the country's largest science agency, the Centre National de la Recherche Scientifique (CNRS).

Each of the association's members claims to have suffered as a result of such pressures. For example, the president of the new body - its title stands for "Scientists opposed to the sclerosis of research" - is Claude Reiss, a geneticist who has been in conflict with the CNRS for more than four years.

He claims that officials tried to close his laboratory at the Institut Jacques Monod (IJM) in Paris, where he works on the structure and dynamics of the genome, and to strip him of his job, for reasons that were personal rather than professional.

Following a dispute over a researcher who had asked to work in Reiss's laboratory, Claude Paoletti, then the CNRS's director of life sciences, froze all recruitment to the laboratory on the grounds that a national review board had said that it was not publishing enough scientific papers.

When Reiss showed that its publication rate was more than twice the CNRS average, Paoletti shifted his ground and ordered Reiss's laboratory to be closed because it lacked "real strategy."

Reiss took the CNRS to an industrial tribunal, and the organization backed down just before the case was to be heard. Reiss claims that this action confirmed his suspicions about the CNRS's motivation, although
Paoletti maintains that his decisions were professionally correct, and that there was no personal conflict with Reiss.

But Reiss is now once again facing closure of his laboratory. In June, Jacques Ricard, director of IJM, ordered Reiss to vacate part of his laboratory and join another group at IJM until a laboratory at Gifsur-Yvette became free. "When I was appointed in January 1991, the situation between Reiss and Paoletti was deadlocked", says Ricard. "I thought it best that he [Reiss] should go elsewhere."

Ricard says the move was simply part of his plans to change the staffing at IJM. Reiss says he will go if his name is cleared, if he is allowed to recruit staff, and if the CNRS compensates him for legal costs and loss of research funds.

Pierre Tambourin, Paoletti's successor, says he is confident that a satisfactory arrangement will be quickly found. CNRS says that the incidence of such lawsuits is low considering that it employs more than 11,000 researchers. But resentment about its procedures remains strong.

Another researcher, Hasan Parves, for example, has found himself caught between two administrations. The CNRS is insisting that he move his neurotransmitter laboratory from Paris to the University of Reims, where his wife has recently been given a post. But the university says it does not want him, and will not provide him with either space or money.

The president of the university, Claude Savarin, has stated that the reason for its opposition is that Hasan's wife was appointed "against the wishes of the university", after she defeated the university's preferred internal candidate in a national competition.

Now, even though Hasan has nowhere to go, the CNRS insists he must leave the laboratory he built up over 23 years at the University of Paris South "as soon as possible". Hasan himself is bitter. Despite having published more than 190 papers in international peer-reviewed journals and edited over 16 books, the CNRS has repeatedly denied him research funding, providing just FF25,000 in 23 years. Hasan has had to raise his research funds through collaborations with groups in the United States and Japan, as well as industrial contracts. And despite his success at doing so he has never climbed above the bottom rung of the CNRS promotion scale, and has been denied promotion for 15 years in succession.

The CNRS denies that it is excessively tough on its researchers. It says its only obligation is to pay them a salary, and that it has a duty to fix research priorities and to allocate resources within these priorities.

According to Reiss, however, there is a basic injustice in placing the responsibility on researchers to prove improper treatment by CNRS. To do so, they must go to an administrative tribunal. But this can take several years, by which time the researcher's career and professional reputation may have suffered irreparably.

Another problem targeted by SOS Recherche members is a lack of openness in the CNRS which, they say, encourages nepotism and abuse of power. CNRS officials and review committees are widely acknowledged to earmark recruits and promotions to people from their own or colleagues' laboratories (see Nature 352, 555; 1991 ).

Furthermore, French scientists are civil servants and can be dismissed for publicly criticizing government policy or the administration of research. Although such laws are rarely enforced, their existence engenders a reluctance to speak out against the scientific establishment.

The solution, suggests Reiss and other SOS members, is stricter adherence to proper disciplinary procedures, and faster and more open hearings of scientists' complaints. Both, they say, would be in the interests of French science.

Declan Butler

\section{Nature news staff} ordered both researchers to leave the observatory within two weeks. The following month the CNRS sent Reinisch and Fernandez to share an unequipped room in a geology institute $20 \mathrm{~km}$ away.

Later in 1991, the administrative tribunal of Nice ruled that Michard's action had been an abuse of power and should be revoked. But the CNRS has never reinstated the researchers. The final chapter occurred in the early morning of 6 June last year. Removal men, supervised by the CNRS regional director, packed the researchers' archives at the observatory into 58 cardboard boxes and shipped them to their new institute.
David Dickson has been appointed News Editor of Nature. Alison Abbott has become Senior European Correspondent, and will continue to be based in Munich. Declan Butler has joined the Nature staff as European Correspondent, and will be based in Paris. 